\title{
Japanese science agency targets space, genome
}

\section{-Module for US space station is a centrepiece - 'Inspiration' for interdisciplinary research}

\section{Tokyo}

JAPANESE space efforts are set to continue their rapid growth, as the Science and Technology Agency (STA) has requested a 10 per cent increase in funds for that programme over the next fiscal year. The agency also says it is placing new emphasis on research on the human genome with a proposed jump in funding of more than 50 per cent, although the total investment remains small by international standards.

Those are the highlights of the budget request submitted by the agency last week to the Ministry of Finance. The request will be trimmed in negotiations with the finance ministry before it is submitted to the Diet early next year, but no major changes are likely.

The budget is dominated by space and nuclear power, which account for more than 80 per cent of the proposed expenditure. The large increase requested for space will only serve to strengthen the view, held by other government organizations, that the agency is primarily an organization for the development of space and nuclear power, rather than science and technology in general as its name implies.

Compared with other government ministries and agencies, which must operate under very strict budget limits, the STA has greater freedom to expand its budget - hence the comparatively large overall increase of 6.4 per cent requested. In particular, the agency has flexible funding limits on international projects run under intergovernmental agreements, the prime example of which is the US space station. Japan's commitment to it adds enormously each year to the agency's outlay for space, leading even some agency officials to say that the space budget is becoming lopsided.
Most of the more than $¥ 13,000$ million ( $\$ 100$ million) increase in expenditure for space goes to development of the Japanese module for the US space station, for which the agency has requested $¥ 28,236$ million, up from $¥ 17,958$ million this year. There is also a large increase for the Advanced Earth Observation Satellite, with a proposed budget of $¥ 11,833$ million, or almost double that of this year. The increase for the Earth-observing satellite, which will carry sensors built by the United States and France as well as Japan, accounts for a large proportion of the increase in the agency's proposed outlay for the 'Green Planet Project', which aims at observing the global environment.

The budget request for human genome research has been increased to $¥ 1,520$ million ( $\$ 11$ million). About $¥ 280$ million ( $\$ 2$ million) in new funds will be allocated to establishing an international computer link between the Japan Information Center of Science and Technology and the genome data base at Johns Hopkins University in the United States. The Institute of Physical and Chemical Research will be given a similar boost in funds to $¥ 861$ million ( $\$ 6.4$ million) to expand preliminary research on the human genome.

The genome research will focus on mapping and the build-up of DNA libraries, and the development of informationprocessing systems and DNA sequencing technology, before embarking on a fullblown project to sequence the human genome from 1995, agency officials say. But ambitious plans by some agency members to establish a new semi-private organization to carry out the work have been postponed until nearer the time of the second phase.

Among the STA's new projects is a BUDGET REQUEST FOR SCIENCE AND TECHNOLOGY AGENCY

\begin{tabular}{|c|c|c|}
\hline $\begin{array}{l}\text { th } \\
\text { mil }\end{array}$ & $\begin{array}{l}\text { ousand } \\
\text { ion yen }\end{array}$ & $\begin{array}{r}\% \text { change } \\
\text { from } 1991\end{array}$ \\
\hline Total R \& D budget & 556.1 & +6.4 \\
\hline Special Promotion Funds & 11.1 & +5.7 \\
\hline Space & 144.9 & +10.0 \\
\hline Nuclear Energy & 317.3 & +3.5 \\
\hline SOR (Spring-8) & 7.2 & +47.1 \\
\hline Ocean Research & 11.5 & +7.6 \\
\hline ERATO & 6.4 & +12.3 \\
\hline Human Frontier Science Program & $2.5 *$ & +13.6 \\
\hline Green Planet Project & 19.6 & +90.3 \\
\hline Sakigake Research & 1.2 & +140.0 \\
\hline Inspiration & 0.3 & (new) \\
\hline Human Genome & 1.5 & +66.7 \\
\hline
\end{tabular}

* Ministry of International Trade and Industry has requested $¥ 1.7$ thousand million for Frontiers, bringing total request to $¥ 4.2$ thousand million. which is intended to provide three-year grants of about $¥ 20$ million $(\$ 150,000$ ) a year to young researchers from universities, government and industry, will be given a large increase to $¥ 1,175$ million. This will allow the agency to award 24 new grants next year in addition to 36 soon to be awarded this year.

The agency has been swamped with more than 460 Sakigake grant applications in the past few weeks, about half of them from universities and university-related institutes. But it remains to be seen if the Ministry of Education, Science and Culture, a bitter rival of the Science and Technology Agency, will allow the university researchers under its jurisdiction to accept any Sakigake awards.

Also included in the budget of the Science and Technology Agency (STA) is a surprising request of $¥ 488$ million ( $\$ 3.6$ million) for research on development of a large solid-fuel rocket in collaboration with the academic Institute of Space and Astronautical Science.

It was only a few weeks ago that the agency submitted a proposal to the Space Activities Commission for joint development of the rocket (Nature 352, 181; 18 July 1991). The decision by the commission and the institute to accept the proposal has been much faster than most observers expected, allowing the agency to submit a budget request this year.

The $\mathrm{J}-1$ rocket, as it is to be called, will combine the space institute's M-3SII rocket with the solid-fuel booster rocket of the $\mathrm{H}$ II rocket, being developed by the STA's National Space Development Agency. J-1 will be capable of lifting medium-sized, one-ton satellites into low Earth orbit at very low cost.

David Swinbanks

\section{British Science}

WE shall be publishing on 12 September Nature's Manifesto for British Science, which will be offered without charge to any one of the political parties contesting the next general election, and in the belief that it is an improvement on their own version.

Following publication, on Friday 13 September, there will be a public meeting at the Royal Institution, Albemarle Street, London W1 at which Sir Mark Richmond, chairman of the Science \& Engineering Research Council, will be the principal speaker. The chairman will be John Maddox, Editor of Nature. The meeting will start at 9.45 a.m. and end at $12.45 \mathrm{p} . \mathrm{m}$. The political parties will be invited to send representatives, but there will be ample time for discussion. Those wishing to attend should apply for tickets to Mary Sheehan, Nature, 4 Little Essex Street, London WC2R 3LF. 